\title{
Propelling the future - the meaning of ACARE VISION 2050 for the future development of propulsion systems for aircraft
}

\begin{abstract}
In the year 2000, a group of personalities of aerospace industry, government and research institutes formed the ACARE ("Advisory Committee on Aerospace Research in Europe") and established the well-known VISION 2020. This vision reflects the targets to reduce the environmental impact of air traffic: reducing both carbon dioxide and noise emissions by half and nitrogen oxide emissions even by $80 \%$. Industry and university partners since then jointly defined measures to achieve these challenging goals. Many research programs were implemented funded by national and international bodies, such as the European Union within the Framework program. However, the current status still inhibits further needs to install intense research work.
\end{abstract}

Key words: aircraft, development of propulsion systems, ACARE

\section{Napęd przyszłości - znaczenie ACARE VISION 2050 dla przyszlego rozwoju systemów napędowych statków powietrznych}

W roku 2000 grupa specjalistów z przemystu lotniczego, rządów i instytutów badawczych z całej Europy utworzyła ACARE (Komitet Doradczy ds. Badań Lotniczych w Europie). Komitet ten ustanowit projekt VISION 2020, którego celem jest zmniejszenie oddziaływania na środowisko ruchu lotniczego przez: zmniejszenie emisji dwutlenku węgla $i$ hałasu o połowę oraz zmniejszenie emisji tlenków azotu nawet o 80\%. Członkowie ACARE wspólnie określili środki i czas potrzebne do osiagnięcia tych celów.

Słowa kluczowe: statki powietrzne, rozwój systemów napędowych, ACARE

\section{Introduction}

The ACARE now plans for a strategic research agenda: the VISION 2050, giving a time horizon, which enables long-term projects to be planned and performed. This prospect reflects the expected development of air traffic, which is shown in Figure 1. Air traffic is expected to grow significantly faster than the world economy in total. In order to keep the environmental implications small, the overall air traffic system has to be substantially improved. This includes all technical sectors: aircraft, propulsion, air traffic operation $\&$ control, a lot of socio-economic areas around airports and so on. This paper will concentrate on the requirements for new approaches for aerospace propulsion system. In order to do so, it has to be considered, which type of aircraft and thus range of thrust is promising the most saving in fuel consumption and noise reduction. Figure 2 shows the expected distribution of aircraft types until 2029. It reveals clearly, that the fraction of single and twin aisle aircraft will grow from the current $80 \%$ up to value of $91 \%$. This means, a thrust range of about 20000 to 35000 pound force should be addressed in the first place to ensure the maximum benefit. The financial market share of this segment is predicted to be around 2.5 Billion US\$ and thus certainly represents an attractive area of activities.

\section{The current status}

The fuel burn of a propulsion system to deliver a given thrust can be represented by two parameters, the thermal efficiency and the propulsive efficiency. Thermal efficiency is mainly dictated by the core system with the parameters

\section{Wprowadzenie}

Programy badawcze wchodzące w skład projektu VISION 2020 realizowane były ze środków państw zaangażowanych w ten projekt i organizacji międzynarodowych, takich jak Unia Europejska. Obecna sytuacja ekonomiczna na świecie hamuje dalsze podejmowanie intensywnych prac badawczych. $\mathrm{Z}$ tego powodu komitet ACARE przedstawił długoczasowy plan strategiczny badań: VISION 2050, który skupia się na planowaniu i prowadzeniu projektów długoterminowych. Ten plan uwzględnia przewidywany rozwój ruchu lotniczego, który został przedstawiony na rys. 1. Uważa się, że natężenie ruchu lotniczego będzie wzrastać znacznie szybciej niż cała światowa gospodarka. Aby nie zwiększać jego oddziaływania na środowisko, należy znacznie poprawić ogólny system ruchu lotniczego. Dotyczy to wszystkich sektorów technicznych: samolotów, napędów, obsługi i kontroli ruchu lotniczego, wielu obszarów społeczno-gospodarczych wokół lotnisk itd. Ten artykuł będzie koncentrował się na tematyce dotyczącej nowego podejścia do systemu napędu lotniczego. W pierwszej kolejności należy rozważyć, który typ samolotu, a tym samym zakres ciągu silników, jest najbardziej korzystny pod względem zmniejszenia zużycia paliwa i redukcji hałasu. Na rysunku 2 przedstawiono spodziewany udział poszczególnych typów samolotów w eksploatacji do roku 2029. Z analizy rysunku można zauważyć, że samoloty jedno- i dwuosobowe zamiast obecnych $80 \%$ będą stanowiły $91 \%$ liczby samolotów. $Z$ tego wynika, że aby uzyskać maksymalne korzyści ekologiczne, modyfikacje należy zacząć od silników o sile napędowej od 


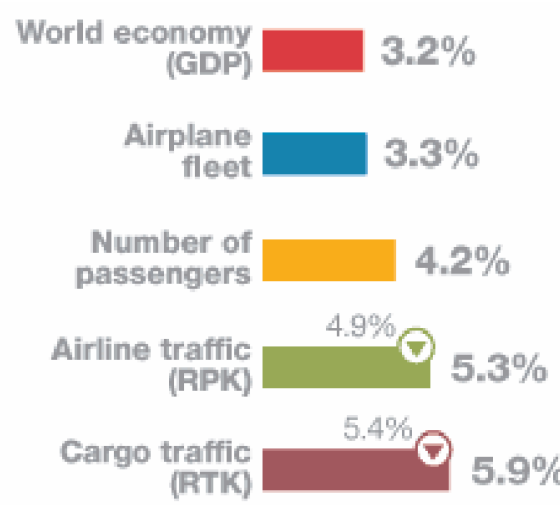

Fig. 1. Growth of Air Traffic from 2009 to 2029 (Boeing Market Outlook 2009)

Rys. 1. Wzrost ruchu lotniczego od $2009 \mathrm{r}$. do 2029 r. (Boeing 2009)

overall pressure ratio (OPR) and turbine entry temperature (TET). Both are connected with each other and have increased substantially through the last decades. However, available turbine materials set limits for efficiency improvements. Nowadays a significant amount of air has already to be used to cool the turbine blades in order to withstand the high combustion temperatures around $1600 \mathrm{~K}$. This reduces the thermal efficiency, so another way for improvement needed to be sought.

The propulsive efficiency proved to be highly effective for the overall reduction of fuel burn. It results mainly from the overall mass flow, so the bypass engine was invented, delivering much more air flow than a simple turbojet engine. While early turbo jet engines featured only a single flow path, current propulsion systems for civil applications are based on high bypass ratio engines. These engines consist of a core gas generator delivering sufficient power to drive a separate

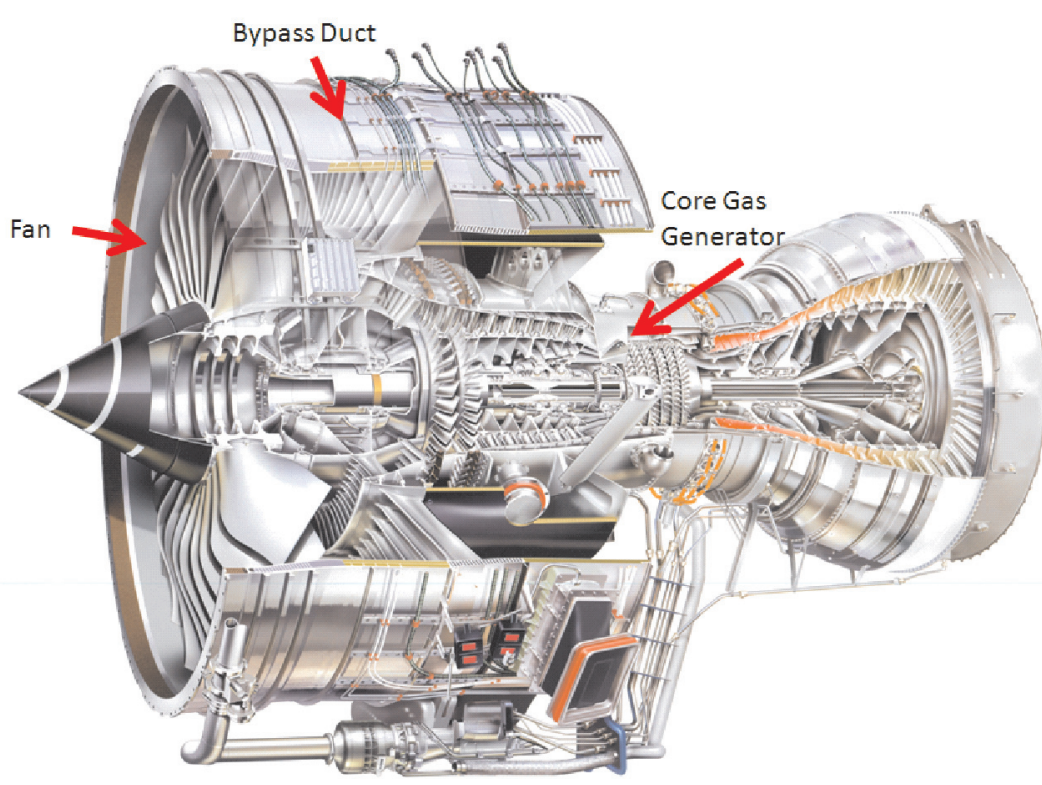

Fig. 3. High bypass turbofan engine (Courtesy of Rolls-Royce)

Rys. 3. Dwuprzepływowy turbinowy silnik odrzutowy o dużym stopniu dwuprzeplywowości (dzięki uprzejmości Rolls-Royce) mld USD.
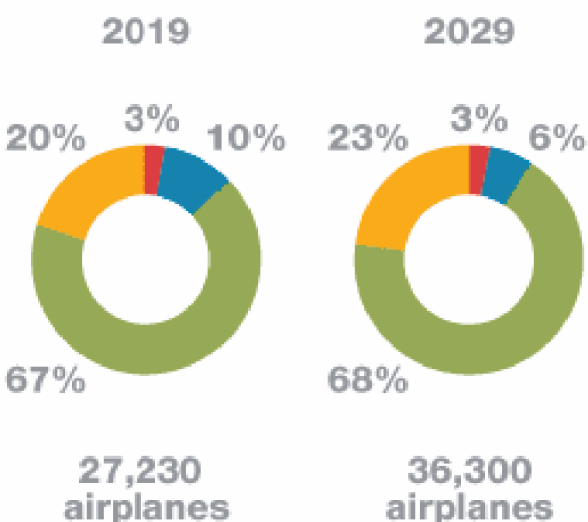

27,230

airplanes

airplanes

Regional jets

Fig. 2. Fleet Development (Boeing Market Outlook 2009)

Rys. 2. Rozwój floty (Boeing 2009)

ok. 89000 N do 156000 N. Silniki tej wielkości stanowią również atrakcyjny obszar działalności dla wielu firm, gdyż ich wartość na rynku jest przewidywana na ok. 2,5

\section{Aktualny stan techniki}

Spalanie paliwa w układzie napędowym, by zapewnić siłę napędową, może być opisane dwoma parametrami: sprawnością cieplną i sprawnością napędu. Sprawność cieplna zależy głównie od układu rdzenia i jego parametrów: sprężu spiętrzenia (OPR) i temperatury przed turbiną (TET). Są one ze sobą powiązane i uległy znacznemu wzrostowi przez ostatnie dziesięciolecia. Obecnie dostępne materiały na turbiny stwarzają ograniczenia modyfikacji zwiększających sprawność. Obecnie znaczna ilość powietrza jest zużywana do chłodzenia łopatek turbin w celu zwiększenia wytrzymałości na wysokie temperatury spalania wynoszace około $1600 \mathrm{~K}$. Wpływa to na zmniejszenie sprawności cieplnej, więc należy szukać innego sposobu zwiększania sprawności napędowej.

Sprawność napędu jest bardzo ważna w ogólnym zmniejszaniu zużycia paliwa. Siła napędowa wynika głównie z ogólnego przepływu masy, więc został wynaleziony silnik dwuprzepływowy, zapewniający znacznie większy przepływ masy niż jednoprzepływowy turbinowy silnik odrzutowy. Wczesne turbinowe silniki odrzutowe charakteryzowały się tylko jedną ścieżką przepływu, natomiast systemy napędowe do zastosowań cywilnych są oparte na silnikach o dużym stopniu podziału strumienia. Te silniki składają się z rdzeniowego generatora gazu i zapewniają moc potrzebną do napędu wału, na którym jest wentylator. Ten duży wentylator dostarcza 


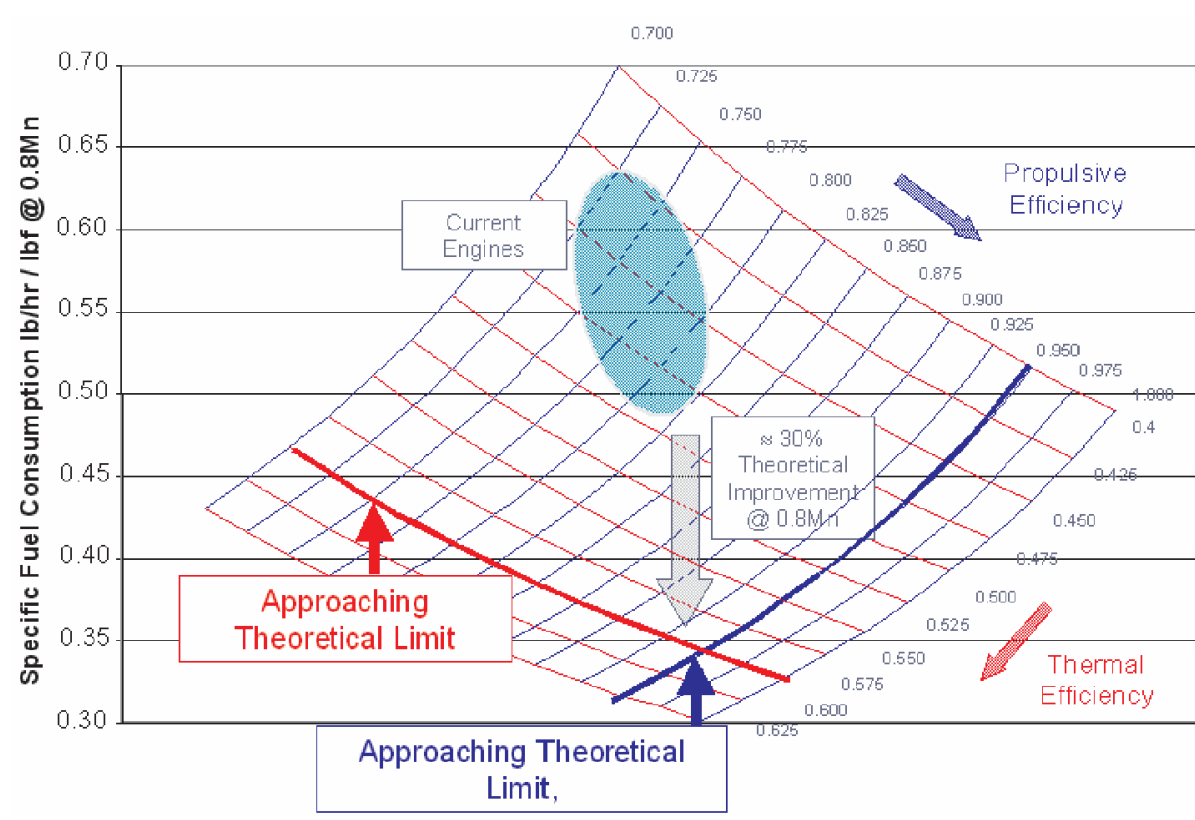

Fig. 4. Limits for the increase of propulsive and thermal efficiency (Rolls-Royce, ISABE 2007) Rys. 4. Ograniczenia wzrostu sprawności cieplnej i napędowej (Rolls-Royce, ISABE 2007)

głównego ciągu do napędu samolotu przez wymuszenie dużego przepływu masy powietrza przez kanał zewnętrzny silnika (rys. 3). W wyniku zmniejszenia prędkość strumienia gazów przepływających przez silnik, sprawność napędu zostaje wielokrotnie zwiększona. $\mathrm{Na}$ rysunku 4 przedstawiono potencjalne korzyści, jakie pozwala uzyskać duży współczynnik podziału strumienia, kiedy obie sprawności dążą do maksymalnych wartości. Ograniczenia poprawy sprawności napędowej wynikają ze zwiększającej się produkcji tlenków azotu wraz ze wzrostem temperatury na wejściu do turbiny. Zwiększenie tej temperatury skutkuje zwiększeniem siły napędzającej wentylator o zwiększonej średnicy, dzięki któremu możliwe jest uzyskanie wyższego współczynnika podziału

shaft, which in turn drives the fan. This big fan delivers the main thrust to the aircraft by pushing a high mass flow of air through a bypass (Fig. 3). Since the jet velocity reduces, the propulsive efficiency increases a lot.

Figure 4 shows the potential, which high bypass ratios have, when both efficiencies are driven to their absolute maximum values. The limitations have their origin in the high nitrogen oxide production, when TET is increased further and the higher drag, which results from growing fan diameters, as they would be needed for higher bypass ratios. It has to be recognized, that current jet engines can only deliver up to $30 \%$ of fuel saving. Thus, new concepts and technologies have to be developed to reduce the fuel burn further and to support the ACARE VISION 2050.

\section{The route to improved propulsion systems}

When assessing the alternatives to the current engine systems, it has to be distinguished between near-term and long-term possibilities. The reasons for this are manifold:

- The development and certification cycles in aerospace are significantly longer than in other technical areas

- The life time of aircraft is extremely long and present no chances to introduce principle changes of the system at one single time

- The technology needed to support new cycles and configurations need to be developed first

- The social economic environment might change faster than the plans for changes in technology

In the near-term, the high bypass ratio engines (Fig. 3) are improved on an evolutionary basis. This contains for example the introduction of better materials and aerodynamics, increased bypass ratio by even bigger fans, the BLISK technology for compressor discs as well as lean-burn combustion concepts. The advantage of these changes is clearly the time-wise very close availability as well as the rapid and strumienia. Należy zaznaczyć, że obecne silniki odrzutowe mogą zapewnić jedynie do $30 \%$ oszczędności paliwa. Tak więc trzeba opracować nowe koncepcje i technologie w celu obniżenia zużycia paliwa oraz dalej wspierać realizację projektu VISION 2050.

\section{Droga do poprawy systemów napędowych}

Przy ocenie alternatywnych koncepcji w odniesieniu do koncepcji obecnych systemów silnika należy wyróżnić krótkoterminowe i długoterminowe możliwości rozwoju systemów napędowych. Przyczyny tego podziału są wielorakie:

- rozwój i cykle certyfikacji w lotnictwie są znacznie dłuższe niż w innych obszarach technicznych

- żywotność samolotu jest bardzo duża i nie ma możliwości wprowadzenia zasadniczych zmian systemowych w jednym czasie

- w pierwszej kolejności należy udoskonalać technologie wymagane w nowych cyklach i konfiguracjach konstrukcyjnych

- otoczenie (środowisko) społeczno-gospodarcze może zmienić się szybciej niż planowane zmiany technologii w zakresie systemów napędowych.

W najbliższej perspektywie silniki o wysokim współczynniku podziału strumienia (rys. 3) będą modyfikowane na zasadzie ewolucji obecnie istniejących rozwiązań. Polega to np. na wprowadzeniu lepszych materiałów, poprawie aerodynamiki, zwiększaniu stopnia podziału strumienia (przez zastosowanie jeszcze większych wentylatorów), wprowadzaniu technologii BLISK dla wirników sprężarki, jak również rozwoju systemów spalania mieszanek ubogich. Zaletami takich modyfikacji są krótki czas oraz niski koszt wdrożenia do produkcji. Jednak zmiany te pozwalają zmniejszyć zużycie paliwa tylko w niewielkim stopniu. 
cost-effective introduction. On the other hand, they only offer a limited potential for fuel burn reduction.

In order to support the targets of VISION 2050, the following options are followed

- New engine concepts

- New combustion concepts

- Alternative fuels and new energy sources

- The "More Electric Aircraft": Replacing the hydraulic and pneumatic subsystems by an all electric system

- Changes in the aircraft configuration and integration of the propulsion system

Due to the high variety and complexity of these options, only the main engine related developments shall be described in the following chapters.

\section{New engine concepts}

Concerning the mid-term possibilities, the overall efficiency of the conventional design is increased in a bigger step. One example for this is the just announced aircraft A320NEO by Airbus, which beside new wings introduces also new engine concepts. First delivery of the aircraft shall take place in 2016. However, 95\% of the aircraft structure remains the same as before. With respect to the engine, a new engine concept will be introduced with this aircraft: the "Geared Turbo Fan" (GTF). The PW1000G has been developed by Pratt\&Whitney in the United States and looks like a conventional engine from outside. However, it takes advantage of decoupling the low pressure turbine from the fan by a planetary gear box (Fig. 5). Both turbo components can now work at their individual optimum circumferential speed, which beside the efficiency improvement also leads to a significant reduction in the number of turbine stages. In turn, fewer parts are required and the engine gets shorter and lighter. This concept is in principle known from propeller engines, but has only now been built into a turbo fan. The engine is currently in flight test and demonstrates significant reductions both in fuel burn and noise. However it needs to be considered, that the weight benefit is partly reduced by
W projekcie VISION 2050 rozważa się następujące kierunki rozwoju systemów napędowych:

- nowe koncepcje silnika

- nowe koncepcje spalania

- paliwa alternatywne i nowe źródła energii

- "Bardziej Elektryczny Samolot": zastępowanie hydraulicznych i pneumatycznych podzespołów układami elektrycznymi

- zmiany w konfiguracji statku powietrznego i integracja systemu napędowego.

Ze względu na dużą różnorodność i złożoność tych kierunków rozwoju w następnych rozdziałach opisano tylko główne zmiany silników.

\section{Nowe koncepcje silnika}

Gdy weźmie się pod uwagę średniookresowe możliwości rozwoju silników, to okazuje się, że ogólna sprawność dotychczasowych konstrukcji osiągnęła bardzo wysoki poziom. Przykładem tego jest właśnie zapowiedziany samolot Airbus A320NEO, którego pierwsze dostawy nastąpią w 2016 r. Mimo zastosowania nowych skrzydeł oraz wprowadzenia nowych rozwiązań konstrukcyjnych silnika, 95\% struktury statku powietrznego pozostaje takie samo jak w rozwiązaniach dotychczasowych. W odniesieniu do silnika nowe koncepcje wprowadzane $\mathrm{w}$ tym samolocie to silnik wentylatorowy z przekładnią (GTF) i model PW1000G. Silnik ten został opracowany przez Pratt\&Whitney w Stanach Zjednoczonych i z zewnątrz wygląda jak tradycyjny silnik wentylatorowy. Jednakże jego zaletą, w porównaniu do dotychczas stosowanych silników wentylatorowych, jest odłączana turbina niskociśnieniowa, biorąca napęd $\mathrm{z}$ wentylatora przez przekładnię planetarną (rys. 5). Obydwa turboelementy mogą teraz pracować w ich indywidualnych, optymalnych prędkościach obrotowych. Rozwiązanie to, oprócz poprawy efektywności, pozwala znacznie zmniejszyć liczbę stopni sprężarki. W dalszej kolejności skutkuje to mniejszą liczbą części, dzięki czemu silnik jest krótszy i lżejszy. Ta koncepcja jest w zasadzie znana z silników śmi-

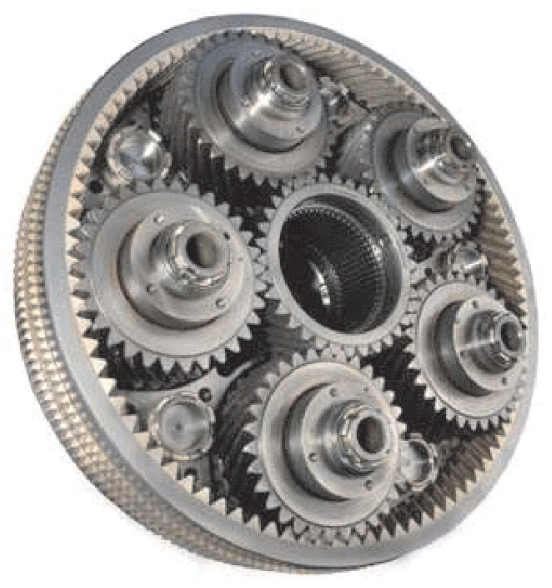

Fig. 5. Planetary Gear Box of the PW1000G engine (Courtesy of Pratt\&Whitney)

Rys. 5. Przekładnia planetarna z silnikiem PW1000G (dzięki uprzejmości Pratt \& Whitney)

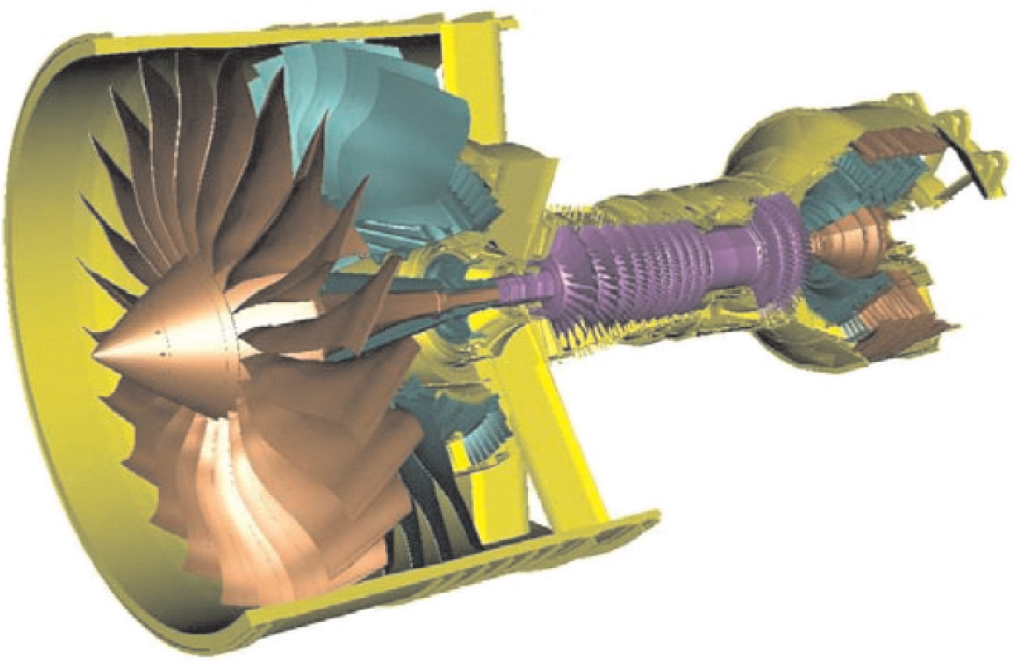

Fig. 6. Counter-Rotating Turbo Fan concept

Rys. 6. Koncepcja silnika wentylatorowego z przeciwbieżnymi wirnikami 
the additional weight coming from the gear box and the high impact of an optimized transmission onto the efficiency of the system. In the same way, maintenance and service times need to be evaluated, before this concept can be introduced into normal operation.

In the far-term, two separately driven rotors could replace a single fan. Figure 6 shows a concept, based on today's appearance of engine, where the bypass is enclosing the fan rotors, counter-rotating to each other. Due to the design, it is referred to as 'Counter Rotationg Integrated Shrouded Propfan (CRISP)'.

A similar setup is the "Open-Rotor" (O/R, Fig. 7). It offers a further, significant reduction in fuel burn and takes advantage of two open rows of blades, counter-rotating as well. Thus the idea of a turboprop engine is taken as basis,

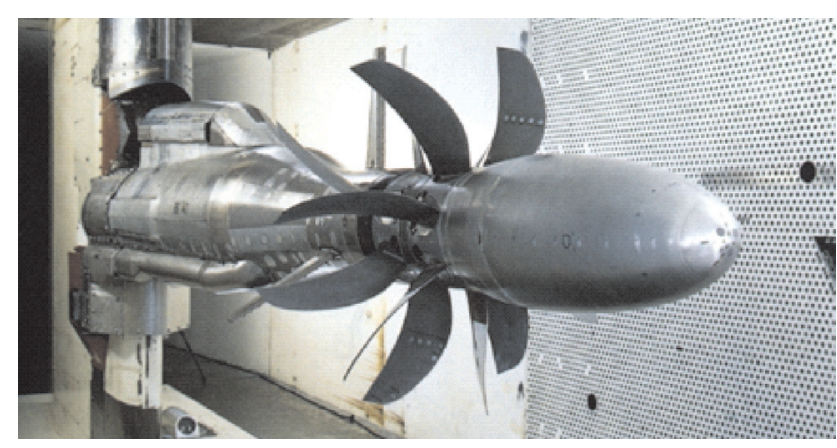

Fig. 7. The Open Rotor Concept (Rolls-Royce)

Rys. 7. Koncepcja uktadu propfan (Rolls-Royce)

while the principle disadvantage of a single propeller is deleted by putting a second propeller behind. This takes out the momentum of the flow in circumferential direction, leading to more thrust at a given rotational speed. Predictions go up to $25 \%$ fuel saving in addition to the already achieved reduction, presenting a concept, which could lead the way for VISION 2050. Major challenges exist with respect to the noise, vibration and the inherently involved smaller flight velocities. Figure 8 contains a comparison of the fuel saving between an O/R propulsion system compared to a conventional high-bypass turbofan. Depending on the installation, the advantage appears to be biggest at flight speeds below $\mathrm{Ma}=0.6$. In addition, integration issues lead to the necessity to think about completely new aircraft configurations.

Even farther away is the "Intercooled-Recuperated Aero Engine" (IRA) concept (Fig. 9). It increases the thermal efficiency of the basic thermodynamic cycle by use of an intercooler between the two compressors of a two shaft engine on the one side and a recuperator behind the engine on the other side. The latter extracts thermal energy from the jet stream, which would otherwise be lost to the environment and feeds it back into the air, before it enters the combustion chamber. By this, fuel can be saved, since the air is hotter already. The transfer of heat within the heat exchangers affects the shape of the thermodynamic cycle as shown in Figure 10. głowych, ale dopiero teraz została zastosowana w silniku turbowentylatorowym. Opisywany silnik jest obecnie w trakcie prób w locie i wykazuje znaczne zmniejszenie zużycia paliwa i większe ograniczenie emisji hałasu. Jednak korzyści wypływające ze zmniejszenia masy samego silnika są częściowo niwelowane przez zastosowanie przekładni, która ma duży wpływ na optymalne przenoszenie napędu, a tym samym na sprawność układu napędowego. W ten sam sposób należy oceniać obsługę i konserwację, zanim konstrukcja ta zostanie wprowadzona do normalnej eksploatacji.

W perspektywie długoterminowej dwa oddzielnie napędzane wirniki mogą zastąpić jeden. Na rysunku 6 przedstawiono koncepcję silnika, która powstała na podstawie aktualnej budowy silnika. W przedstawionym rozwiązaniu zewnętrzny kanał przepływowy silnika łączy przeciwbieżne wirniki. Ze względu na konstrukcję został on określony jako przeciwbieżny zintegrowany, otunelowany wentylator (CRISP). Podobną konstrukcją jest układ propfan (otwarty wentylator) (O/R, rys. 7). Silnik typu propfan pozwala znacznie zmniejszyć zużycie paliwa, a jego konstrukcja składa się z dwóch otwartych przeciwbieżnych rzędów łopatek. Za podstawę tej konstrukcji posłużył silnik turbośmigłowy, jednak umieszczenie drugiego śmigła z tyłu pozwala zniwelować podstawową wadę silnika jednośmigłowego, a zatem wyklucza to pęd przepływu w kierunku obwodowym, co skutkuje większym ciągiem samolotu. Stosowanie konstrukcji typu propfan prognozuje oszczędności paliwa nawet do $25 \%$, oprócz już osiągniętego zmniejszenia w przedstawionej koncepcji - co prowadzi do osiągnięcia celów projektu VISION 2050. Główne wyzwania dotyczą zmniejszenia hałasu, drgań, nieodłącznie związanych z niższymi prędkościami lotu. $\mathrm{Na}$ rysunku 8 przedstawiono porównanie oszczędności paliwa pomiędzy napędami O/R i konwencjonalnym turbowentylatorowym. W zależności od instalacji, korzyści wydają się największe przy prędkościach lotu poniżej $\mathrm{Ma}=0,6$. Ponadto kwestie integracji układu napędowego zmuszają do myślenia o zupełnie nowych konstrukcjach samolotów.

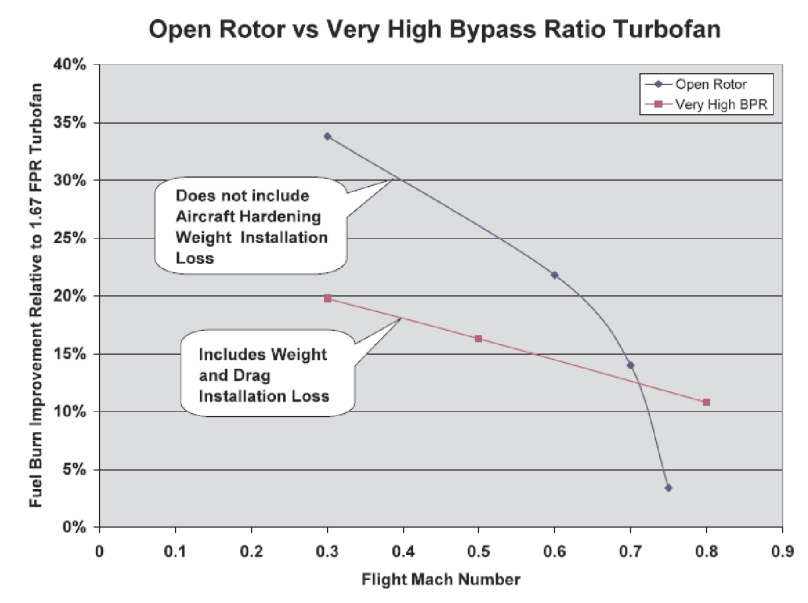

Fig. 8. Fuel Saving of Open Rotor against High Bypass Ratio Turbofan (Mazzawy)

Rys. 8. Oszczędność paliwa silnika typu propfan w porównaniu do silnika turbowentylatorowego o dużym stopniu podziału strumienia (Mazzawy) 


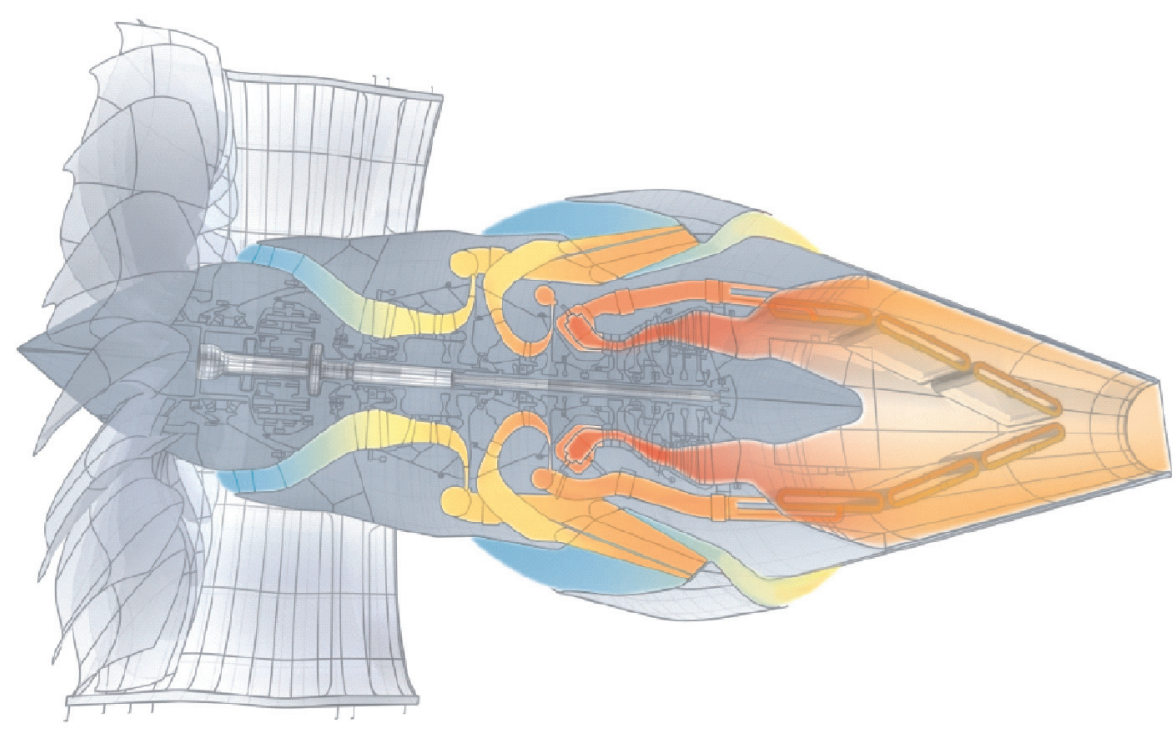

Fig. 9. The Intercooled-Recuperated-Aero (IRA) Engine Concept (NEWAC)

Rys. 9. Koncepcja silnika z wewnętrznym chłodzeniem i odzyskiwaniem ciepła (IRA) (NEWAC)
W jeszcze dalszej perspektywie czasowej można oczekiwać silnika z wewnętrznym chłodzeniem i odzyskiwaniem ciepła (IRA) - rys. 9. Koncepcja ta pozwala zwiększyć sprawność cieplną podstawowego cyklu termodynamicznego przez zastosowanie chłodnicy między dwoma sprężarkami silnika dwuwirnikowego $\mathrm{z}$ jednej strony i wymiennika ciepła za silnikiem z drugiej strony. Wymiennik ciepła służy do odzyskiwania energii cieplnej prądu strumieniowego, która w przeciwnym razie byłaby usunięta do środowiska, i podaje ją z powrotem wraz ze świeżym powietrzem do komory spalania. Pozwala to zaoszczędzić paliwo, ponieważ powietrze jest już wstępnie ogrzane. Wymiana

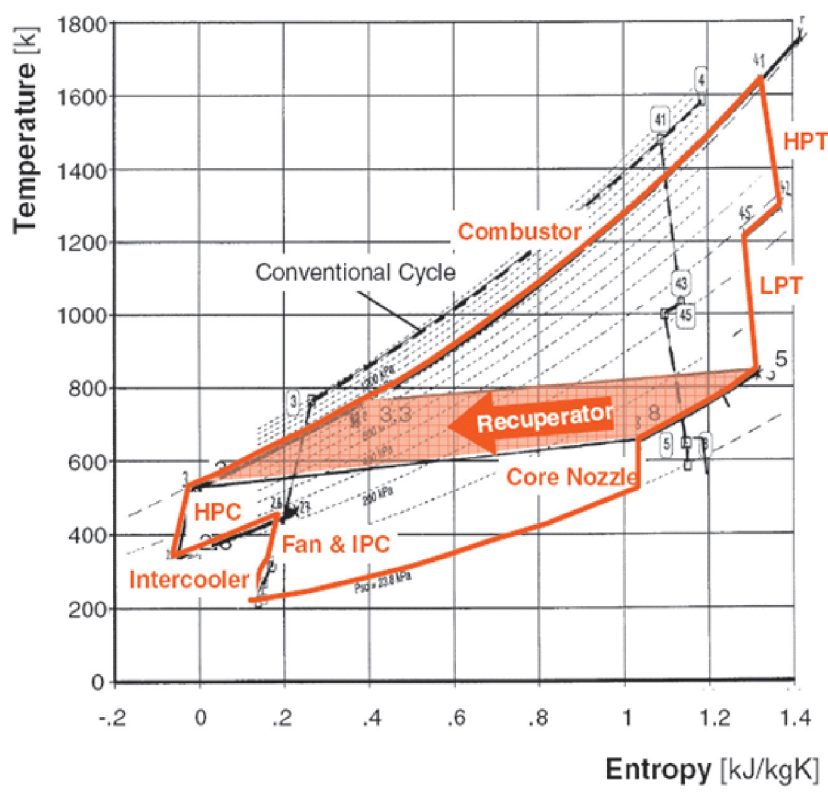

Fig. 10. Change in the thermodynamic cycle by introduction of the IRA concept (MTU)

Rys. 10. Zmiana obiegu termodynamicznego przez wprowadzenie koncepcji IRA (MTU)

\section{New combustion concepts}

While carbon dioxide and water vapor emissions cannot be avoided with today's type of fuel, the requirement to reduce nitrogen oxide can only be fulfilled by a lower temperature level of the thermodynamic cycle or new combustion concepts. Since the first measure would lead to a reduction of thermal efficiency, if adopted stand-alone, there is a strong need for new combustion processes.

For combustion engines in general, the two main characteristic numbers are the fuel-to-air ratio AFR and the equivalence ratio $\Phi$. While AFR in the primary combustion zone certainly has to be within certain bounds to ensure a energii w wymiennikach ciepła wpływa na kształt obiegu termodynamicznego, jak to pokazano na rys. 10.

\section{Nowe koncepcje spalania}

Stosując tradycyjne paliwa, nie da się uniknąć emisji dwutlenku węgla i pary wodnej, jednak możliwe jest dążenie do zmniejszenia emisji tlenku azotu przez obniżenie temperatur w cyklu termodynamicznym lub przez zastosowanie nowych koncepcji spalania. Pierwszy sposób, stosowany jako jedyna metoda mająca na celu obniżenie emisji tlenków azotu, prowadzi jednak do zmniejszenia sprawności cieplnej i dlatego potrzebne są nowe koncepcje procesów spalania.

Dla silników spalinowych można wyróżnić dwa charakterystyczne wskaźniki porównawcze, określające skład mieszaniny palnej: stosunek ilości powietrza do ilości paliwa (AFR) oraz współczynnik nadmiaru powietrza $(\Phi)$. Stosunek ilości powietrza do ilości paliwa należy tak dobrać, aby zapewnić stabilne spalanie w głównej strefie spalania, natomiast współczynnik nadmiaru powietrza powinien być dostosowany do poprawy poziomu zanieczyszczenia. Od wysokości temperatury spalania ściśle zależy szybkość tworzenia się tlenków azotu. Niekorzystne z powodu tworzenia tlenków azotu jest również spalanie mieszanek stechiometrycznych (określane współczynnikiem równoważności $\Phi$ 1). Jednak obecnie produkowane silniki, ze względu na możliwość zapewnienia szerokiego zakresu regulacji mocy napędowej, pracują w wymienionych niekorzystnych warunkach spalania (rys. 11). Podczas startu mieszanka paliwowopowietrzna musi mieć skład około stechiometryczny $\Phi \sim 1$, co sprzyja powstawaniu tlenków azotu. Podczas pracy silnika na biegu jałowym głównymi produktami spalania są tlenki węgla i niespalone węglowodory. Podstawowym zadaniem jest uniknięcie spalania mieszanek o składzie stechiometrycznym bez wpływu na wymagany zakres mocy silnika. Można to osiągnąć przez spalanie mieszanek ubogich lub bogatych. Spalanie mieszanek bogatych powoduje zwiększo- 
stable combustion, the equivalence ratio may be adjusted to improve the level of pollution. Since the nitrogen production is strongly connected to the temperature level, it should be avoided to burn within the stoechiometric region $(\Phi \sim 1)$. This however is the case with today's aircraft engines, since they need a wide control range to cover minimum and maximum thrust requirements (Fig. 11). At take-off conditions, the fuel-air mixture needs to burn close to $\Phi \sim 1$, developing high levels of nitrogen. At idle conditions, mainly carbon monoxide and unburned hydro carbons are produced. So the task at hand is to avoid stoechiometric combustion without affecting the required power range of the engine. This can be achieved by lean or rich conditions. The latter approach means additional soot emissions, so it can only be realized with a zone of lean combustion following the rich region to consume the soot within the combustion chamber. Lean combustion on the other hand gives challenges in terms of flame stability. Thus, three options are basically available:

1. Lean combustion:

Operation at $\Phi \sim 0.5$, where the different operating points are addressed by staging concepts

2. Lean, premixed and prevaporized combustion:

As 1), but with a premixing of air and fuel upfront of the injection, combined with a pre-heating of this mixture to achieve a bigger surface for proper combustion. This leads to stable combustion at different operating points, but requires protection against pressure waves developing against the fuel flow into the compressible part of the fuel system

3. Rich Burn-Quick Quench - Lean Burn combustion:

This is a very promising approach, where the first combustion zone features high equivalence ratios, then air is mixed very quickly to jump to lean combustion in the second zone. The quick quench avoids nitrogen oxides to be formed, since there is not sufficient time for the chemical reaction to happen. Challenges are mainly the high temperatures to be dealt with in the rich burning zone, where air cannot be used to cool the combustor surface as well as the squeezing of air into a critical combustion zone with the requirement to provide a smooth temperature distribution to the turbine nozzle guide vanes downstream.

The effect of the various concepts onto the nitrogen oxide production is investigated in various research programs on European level. Figure 12 shows an indication of the trend of nitrogen oxide production, depending on the overall pressure ratio (OPR) of the engine compared to the legislation requirements. These are defined by CAEP (Committee on Aviation Environmental Protection) on behalf of ICAO (International Civil Aviation Organization). The results demonstrate, that the targets may be achieved, if the concepts can be developed to a state, where they can be introduced safely and reliably into service. The main challenge is controllability of a safe and stable combustion for all operating conditions of a safety critical system. ną emisję sadzy i dlatego można je realizować tylko ze strefą ubogiego spalania, pozwalającą dopalić sadzę znajdującą się $\mathrm{w}$ komorze spalania, a powstałą $\mathrm{w}$ trakcie spalania mieszanki bogatej. Natomiast podczas spalania mieszanek ubogich występują problemy z zapewnieniem stabilności płomienia. Tak więc rozważane są trzy koncepcje procesu spalania:

1.Ubogie spalanie:

praca w $\Phi \sim 0,5$, gdzie różne punkty pracy zostały określone przez zakres pracy.

2.Ubogie spalanie mieszanki wstępnie wymieszanej i odparowanej:

w punkcie 1. mieszanie powietrza i paliwa następuje za czołem wtryskiwanego paliwa, w połączeniu z podgrzewaniem tej mieszaniny w celu osiągnięcia większej powierzchni dla prawidłowego spalania. Zaletami tego typu spalania jest jego stabilność w różnych punktach pracy, jednak nierozwiązaną jeszcze sprawą jest przepływ paliwa do części sprężającej układu paliwowego.

3. Spalanie bogate - szybkie wygaszenie - spalanie ubogie:

to bardzo obiecujące podejście, gdzie pierwsza strefa spalania charakteryzuje się wysoką równoważnością wskaźników, a następnie powietrze jest mieszane bardzo szybko, aby przejść do spalania ubogiego w drugiej strefie. Szybkie

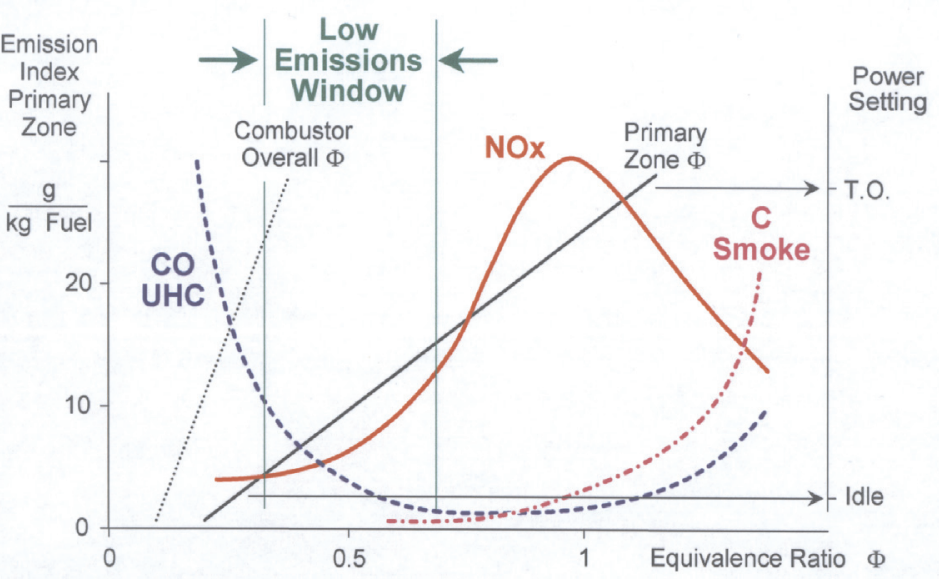

Fig. 11. Emission Indices depending on equivalence ratio

Rys. 11. Emisja składników toksycznych w zależności od współczynnika nadmiaru powietrza

ugaszenie przeciwdziała tworzeniu się tlenków azotu, ponieważ nie ma wystarczającej ilości czasu do wystąpienia reakcji chemicznej ich wytworzenia. Wyzwaniem do rozpatrzenia są głównie wysokie temperatury w bogatych strefach spalania, gdzie powietrze nie może być użyte do chłodzenia powierzchni komory spalania, jak również nie może być wyciskanie powietrza do krytycznej strefy spalania z wymogiem zapewnienia odpowiedniego rozkładu temperatury na łopatkach turbiny.

Wpływ różnych koncepcji spalania na powstawanie tlenków azotu jest badany w różnych programach badawczych prowadzonych przez jednostki należące do ACARE. Na rysunku 12 przedstawiono emisję tlenków azotu, w zależno- 


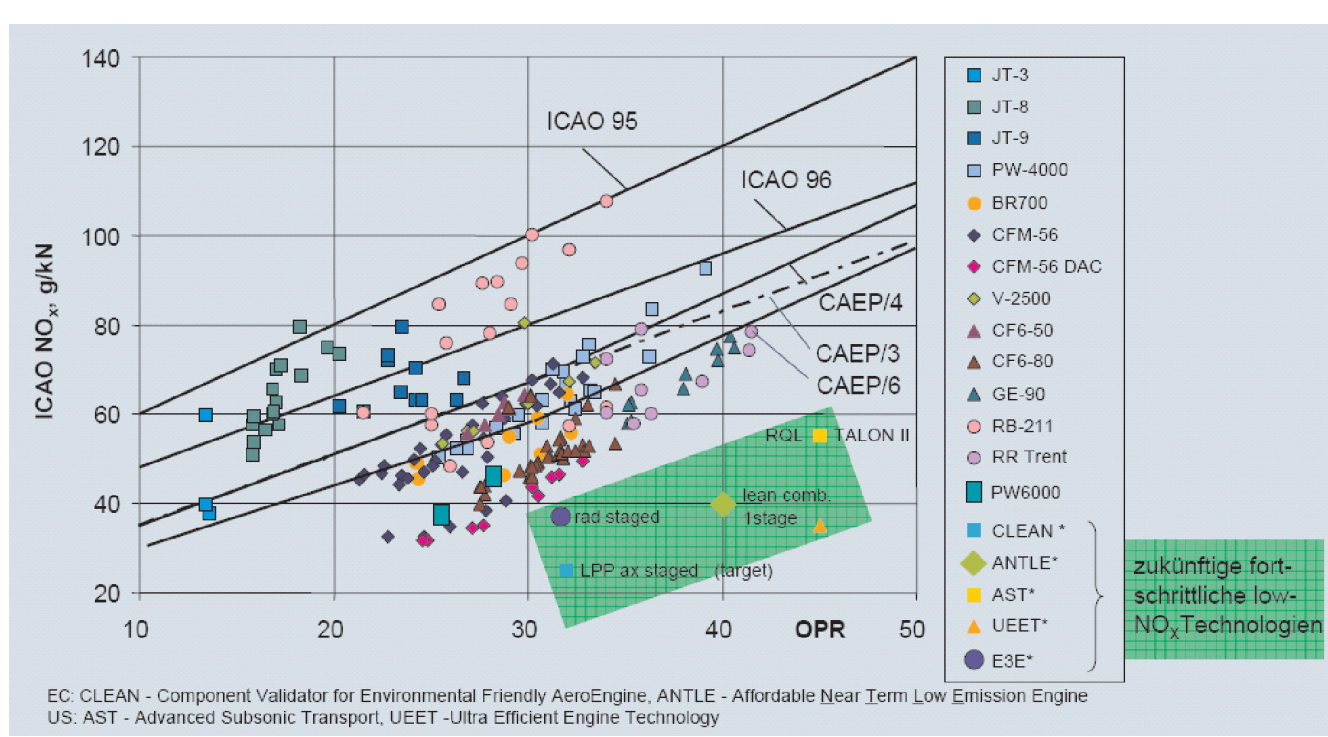

Fig. 12. Reduction of nitrogene oxides by the combustion concepts (E.U. programs CLEAN, ANT

Rys. 12. Emisja tlenków azotu przez silniki o różnych systemach spalania (programy UE CLEAN, ANTLE)

ści od ogólnego sprężu spiętrzenia (OPR) w porównaniu do wymagań obowiązujących przepisów ograniczających emisję tych związków. Ograniczenia te są zdefiniowane przez CAEP (Komitet ds. Lotnictwa i Ochrony Środowiska). Wyniki prowadzonych badań wskazują, że można sprostać stawianym ograniczeniom, jeśli koncepcje będą tak dopracowane, aby mogły być bezpiecznie i niezawodnie wprowadzone do eksploatacji. Głównym wyzwaniem jest kontrolowanie bez-

\section{Alternative fuels and new energy sources}

Discussions are going on about the replacement of kerosene with alternative fuels, which are not based on hydrocarbons. However, it needs to be kept in mind, that safety, energy density, cost, global availability \& environmental impact are all critical for aviation fuel. In all of these aspects, kerosene is very difficult to beat. Two options are currently under discussion: synthetic kerosene and liquid hydrogen.

Synthetic kerosene, manufactured from biomass is a real possibility, but expensive. Currently bio fuels are already in use as a kerosene extender with a maximum part of $10-20 \%$. Main issues are the high freezing temperature of $-10{ }^{\circ} \mathrm{C}$ to $0{ }^{\circ} \mathrm{C}$ and the $1 / 3$ less power density. In addition, the whole life cycle $\mathrm{CO}_{2}$ needs to be considered as well as other pollutants and particulates. Until these issues are solved, the view is to use alternative fuels based on bio mass preferentially for land based applications, until improved solutions to increase availability, applicability and decrease cost are developed.

The second option would be liquid hydrogen. Several proposals have been made to use liquid hydrogen as propellant for aircraft. It would delete all $\mathrm{CO}_{2}$ production $(3.1 \mathrm{~kg}$ per kg fuel), but would inherently produce a much bigger amount of water vapor to be exhausted into the atmosphere (factor 2.5 compared to kerosene). It is not yet clear, what the impact of water in high altitudes will be. The properties of $\mathrm{LH}_{2}$, relative to kerosene, at equal energy content demonstrate a much lower mass (factor 2.8), but a much higher volume (factor 4). Thus introducing this type of fuel would require significantly bigger tanks than nowadays and these tanks would need to isolate the hydrogen, which is liquid only below $-253{ }^{\circ} \mathrm{C}$ ! Beside the resulting airframe issues including integration, the introduction of liquid hydrogen would also need a complete change in infrastructure and logistics due to these reasons. As for the bio fuels, the whole well to wheel cycle needs to be looked at to judge on the effectiveness of changing the fuel. Currently both the cost and piecznego i stabilnego spalania przy wszystkich warunkach pracy systemu.

\section{Paliwa alternatywne i nowe źródła energii}

Toczą się dyskusje dotyczące wymiany nafty na paliwa alternatywne, które nie są oparte na węglowodorach. Jednak należy pamiętać o aspektach istotnych dla lotnictwa i paliwa lotniczego, takich jak: bezpieczeństwo, wartość opałowa, koszty globalne, dostępność i wpływ na środowisko naturalne. Przy uwzględnieniu wszystkich tych aspektów nafta jest na razie niezastąpiona ze względu na swoje dobre właściwości. Dwa paliwa alternatywne są obecnie przedmiotem dyskusji: syntetyczne paliwa lotnicze i ciekły wodór. Syntetyczna nafta produkowana z biomasy daje realną możliwość jej zastosowania, ale jest droga. Obecnie biopaliwa są już w użyciu jako wypełniacz nafty o maksymalnej w niej zawartości 10-20\%. Głównym problemem są wysokie temperatury krzepnięcia: od $-10{ }^{\circ} \mathrm{C}$ do $0{ }^{\circ} \mathrm{C}$ i o 1/3 mniej mocy. Ponadto należy wziąć pod uwagę cały cykl życia $\mathrm{CO}_{2}$, jak również innych zanieczyszczeń i cząstek stałych. Dopóki te kwestie są opracowywane, możliwości wykorzystania alternatywnych paliw opartych na biomasie preferowane są dla pojazdów lądowych, aż do opracowania ulepszonego rozwiązania, tj. zwiększenia dostępności i zmniejszenia kosztów zastosowania. Drugim paliwem jest ciekły wodór. Zastosowanie płynnego wodoru jako paliwa lotniczego powoduje całkowite wyeliminowanie produkcji $\mathrm{CO}_{2}(3,1 \mathrm{~kg}$ na $1 \mathrm{~kg}$ paliwa), a jednocześnie wyemitowanie znacznie większych ilości pary wodnej (współczynnik 2,5 w porównaniu z naftą). Nie jest jeszcze wiadome, jaki wpływ będzie miała znaczna ilość wody na dużych wysokościach. Porównując właściwości $\mathrm{LH}_{2}$ w stosunku do nafty, przy jednakowej zawartości energii, $\mathrm{LH}_{2}$ wykazuje znacznie mniejszą masę (współczynnik 2,8), ale znacznie większą objętość (współczynnik 4). Tak więc wprowadzenie tego typu paliwa wymagałoby znacznie większych niż obecnie zbiorników na paliwo, a zbiorniki te musiałyby zapewnić 
the $\mathrm{CO}_{2}$ balance are far away from making liquid hydrogen suitable for air transport.

\section{The "More Electric Aircraft": replacing the hydraulic and pneumatic subsystems by an all electric system}

Currently, the engine needs to deliver a significant amount of compressed air for various purposes, such as cabin pressurization and anti-icing. This air is taken from the compressor at various positions. Thus a significant amount of energy has already been put into it. In addition, the aircraft requires hydraulic power to drive wing flaps, high-lift devices and so on. In order to improve this, a change of these various power systems towards purely electrically driven accessories is under investigation. This means a significant change in the architecture of the engine:

1. Today's different transfer mechanisms of power from the engine to the customer are all to be exchanged to simple electrical wires. This gives the opportunity to have a de-centralized system with supply devices close to the needed location and thus a much lower system weight and complexity.

2. Transferring electrical energy is much more efficient and safer than delivering air and hydraulic power.

3. The performance of the de-centralized components can be adjusted straight to the requirement at the various flight and power conditions.

4. The compressor design would become much easier, because the casing would not have to feature offtakes at various positions. In addition to a weight saving, it also gives the chance to decrease the tip clearances of the blades, leading to higher efficiency and stability of the compressor.

5. The core size of the engine can become smaller, saving weight and overall size.

6. The interface between the engine and the aircraft would be extremely simplified in design and handling.

Certainly, the disadvantage of the more electric concept is to produce the electric power. The engine would need to drive a large generator, which might be heavy and prone to failure during strongly time-dependent loading. So it will be necessary to introduce a redundant system, which could consist of a second generator, taking some of the weight advantage away. However, this generator could also be used to replace the current air starter and act as a starter-generator. Considering the whole system 'aircraft', the more electric approach is very promising.

\section{Changes in the aircraft configuration and inte- gration of the propulsion system}

Since the development of new propulsion systems cannot be performed separately from the aircraft design task, joint efforts need to be taken to come to a new flying transport system for the future. This includes radical changes in aircraft configurations. Thinking out of the box is required, including the assessment of future needs of travelers and environmental implications. To address these issues in one izolację temperaturową wodoru, który jest cieczą tylko poniżej $-253{ }^{\circ} \mathrm{C}$ ! Oprócz zagadnień wynikających ze zmiany budowy samolotu, w tym rozmieszczenia elementów układu napędowego, wprowadzenie ciekłego wodoru spowodowałoby również całkowitą zmianę infrastruktury i logistyki. Jeśli chodzi o biopaliwa należy przyjrzeć się ich zastosowaniu w rzeczywistych warunkach eksploatacji całościowo i ocenić opłacalność i skuteczność ich wprowadzenia.

\section{7. "Bardziej elektryczny samolot": zastąpienie podzespołów hydraulicznych i pneumatycznych przez elementy elektryczne}

Obecnie silnik musi dostarczać znaczne ilości sprężonego powietrza do takich celów, jak utrzymywanie ciśnienia w kabinie i zapobieganie oblodzeniu. To powietrze jest pobierane $\mathrm{z}$ różnych stopni sprężarki, co pochłania znaczne ilości energii napędowej. Ponadto $\mathrm{w}$ samolocie wymagany jest układ hydrauliczny do napędu klap skrzydłowych oraz innych urządzeń pokładowych. W celu zmniejszenia ilości energii pobieranej z silnika zmiana tych różnych systemów zasilania na napęd elektryczny jest w trakcie badania, a to wiąże się ze znacznymi zmianami konstrukcji silnika:

1. Obecnie stosowane mechanizmy przekazywania mocy z silnika do odbiorników można wymienić na proste przewody elektryczne. Daje to szansę na zdecentralizowanie systemu i zastosowanie urządzeń zasilających w pobliżu odbiorników i tym samym znaczne obniżenie masy systemu i jego złożoności.

2. Przesyłanie energii elektrycznej jest znacznie bardziej efektywne i bezpieczniejsze od dostarczania powietrza czy zasilania hydraulicznego.

3. Wydajność składników zdecentralizowanych może być regulowana $\mathrm{w}$ zależności od zapotrzebowania na energię.

4. Projektowane sprężarki staną się znacznie prostsze, ponieważ obudowa nie będzie musiała spełniać funkcji poboru energii w różnych pozycjach. Oprócz zmniejszenia wagi również pojawia się możliwość zmniejszenia odstępów między krawędziami łopatek a obudową sprężarki. Doprowadzi to do zwiększenia wydajności i stabilności sprężarki.

5. Rdzeń silnika może być mniejszy, przez co zmniejszy się jego masa.

6. Połączenie pomiędzy silnikiem a szkieletem samolotu będzie niezwykle uproszczone w zakresie projektowania i obsługi.

Wadą opisanego rozwiązania jest większe zapotrzebowanie na paliwo do produkcji energii elektrycznej niż w rozwiązaniu stosowanym dotychczas. Silnik musiałby napędzać duży generator, który może być ciężki i podatny na uszkodzenia podczas długiej pracy pod dużym obciążeniem. $\mathrm{Z}$ tego powodu konieczne będzie wprowadzenie dodatkowego systemu, który może składać się z drugiego generatora. Układ ten jednak zniweluje wszystkie korzyści wynikające z zastosowania pojedynczego silnika. Jednak generator może być również używany do zastąpienia obecnego rozrusznika. 
team, multi-disciplinary organizations are created. One example is the 'Bauhaus Luftfahrt e.V.', which was established in November 2005 by the three aerospace companies EADS, Liebherr-Aerospace and MTU Aero Engines together with the Bavarian Ministry for Economic Affairs. It represents a think tank, developing radical new aircraft concepts. Some of these are given in the following pictures, demonstrating,

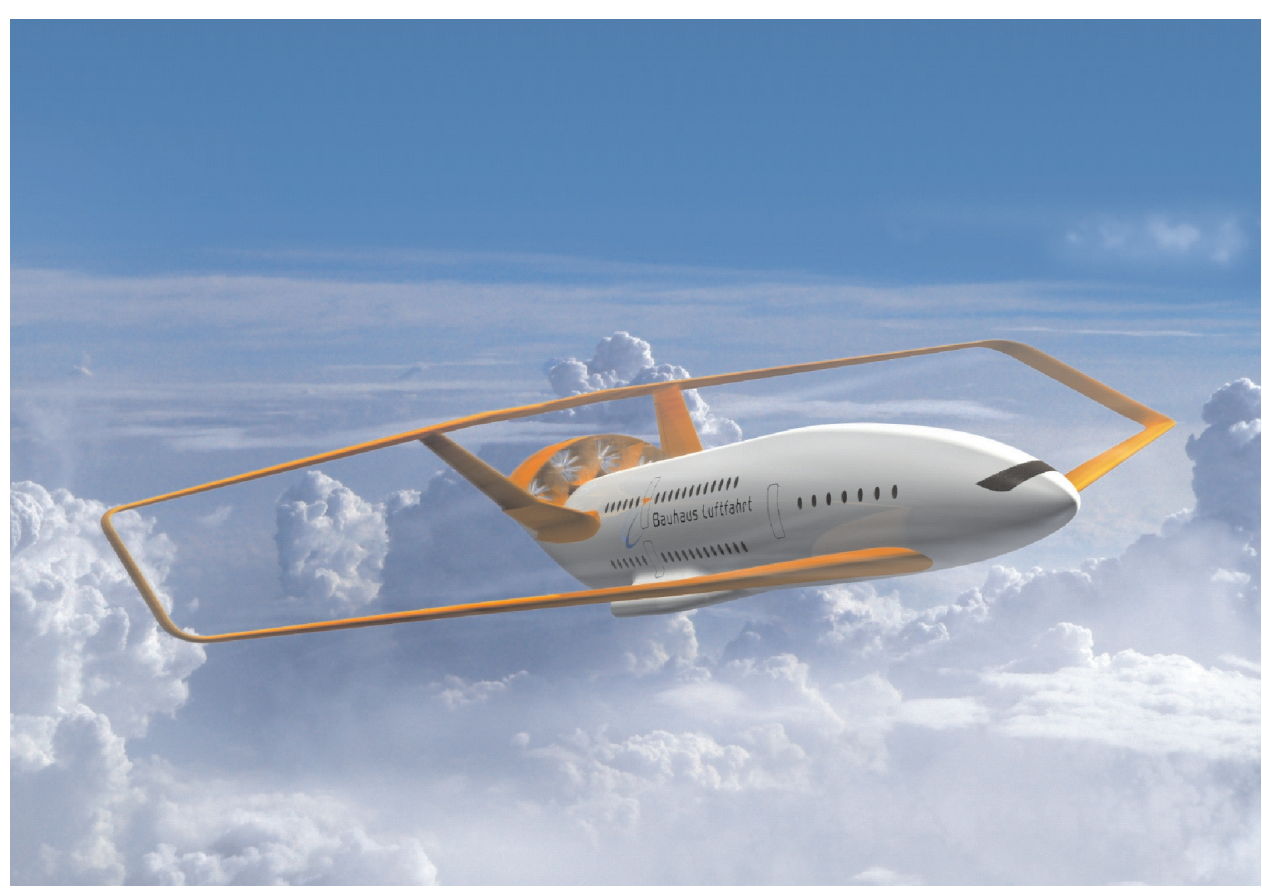

Fig. 13. The ,Claire Liner' (Bauhaus Luftfahrt e.V.) Rys. 13. Claire Liner (Bauhaus Luftfahrt e.V.)

that there is a big space for future development of propulsion systems! Aircrafts of the future could look like the ones given in Figure 13, 14 and 15.

These figures show very different concepts with all types of engine configurations, which have been explained before. The aircraft configurations will require the development of engines, which can be located above the aircraft or integrated into the aircraft body and wing. This means safe design in terms of inlet distortion approaching the fan as well as challenges in the certification, e.g. with respect to critical testing as FBO ("Fan

Fig. 14. Hyliner ESTOL (Bauhaus Luftfahrt e.V.)

Rys. 14. Hyliner ESTOL (Bauhaus Luftfahrt e.V.)
Biorąc pod uwagę cały system "statek powietrzny", posiadanie większej ilości energii jest zaletą.

\section{Zmiany w konfiguracji statku powietrznego i integracji ukladu napędowego}

By osiągnąć zakładane w prowadzonych badaniach projektów cele, nie należy rozwijać nowych układów napędowych bez jednoczesnego rozwijania konstrukcji całych samolotów. Koncepcja ta zawiera radykalne zmiany $\mathrm{w}$ konstrukcjach samolotów. W trakcie projektowania wymagana jest wiedza dotycząca przyszłych potrzeb podróżnych i konsekwencji środowiskowych danego rozwiązania. $\mathrm{Z}$ tego powodu powstają interdyscyplinarne zespoły badaczy, tworzące organizacje. Jednym z przykładów takiej nowoczesnej organizacji jest "Bauhaus Luftfahrt e.V.", która powstała $\mathrm{w}$ listopadzie 2005 r. Utworzyły ją trzy firmy lotnicze: EADS, Liebherr Aerospace i MTU Aero Engines wraz z Bawarskim Ministerstwem Gospodarki. Wymienione podmioty stanowią grupę ekspertów, zajmujących się rozwojem nowych koncepcji samolotów. Niektóre z tych koncepcji samolotów przedstawiono na rys. 13-15.

Zaprezentowane konstrukcje pokazują, że istnieją duże możliwości dalszego rozwoju systemów napędowych. Ilustracje te przedstawiają bardzo różne koncepcje z wszystkimi

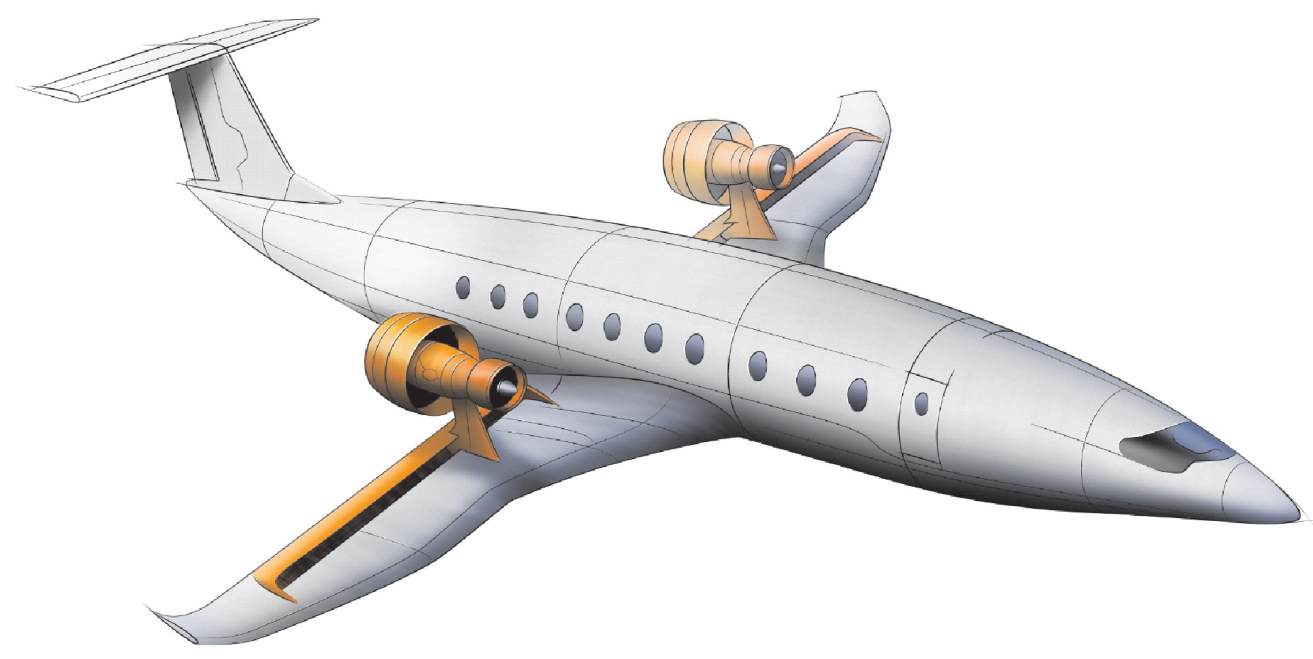




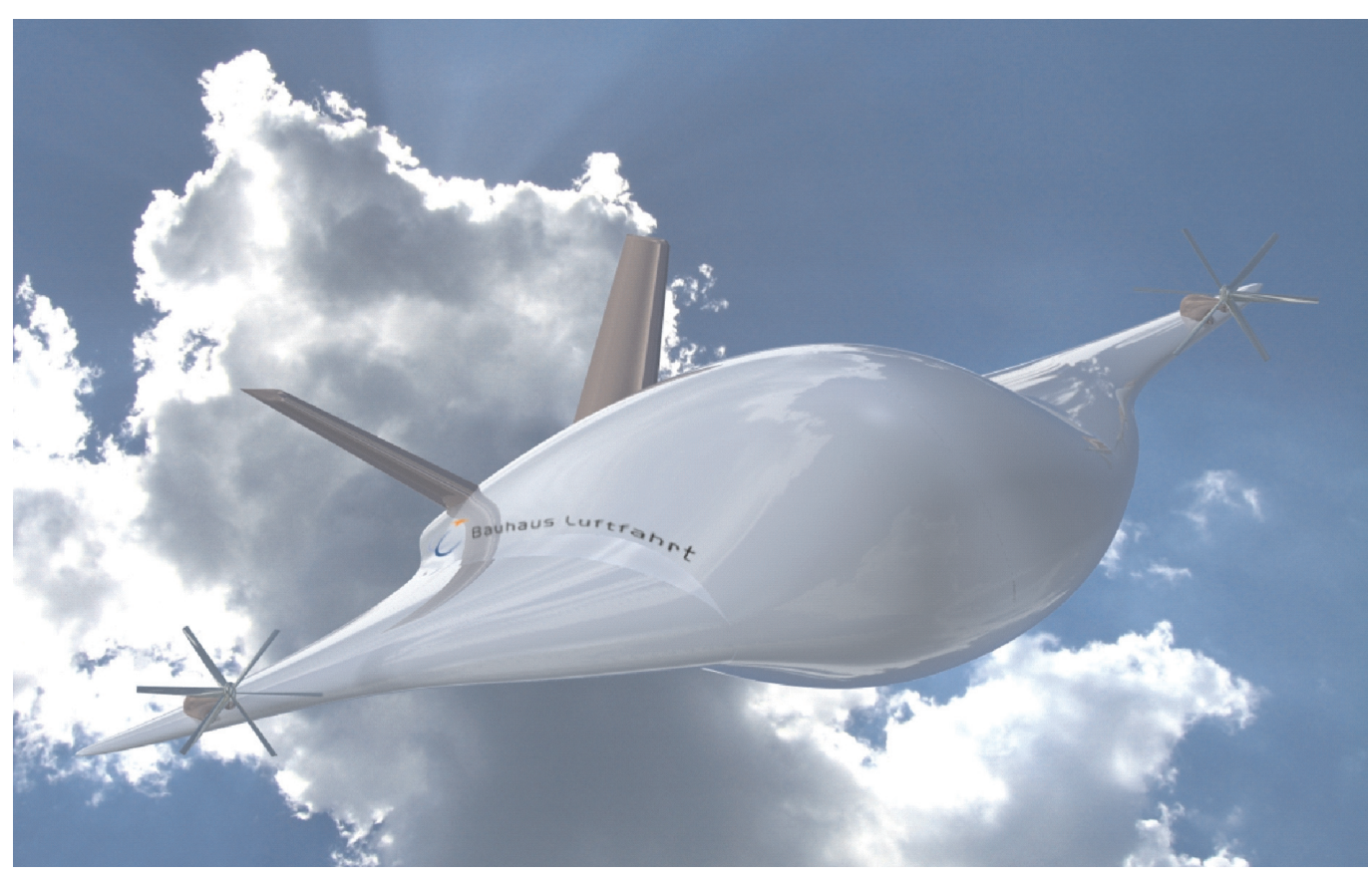

Fig. 15. The VTOL Aircraft (Bauhaus Luftfahrt e.V.)

Rys. 15. Samolot VTOL (Bauhaus Luftfahrt eV.) typami konfiguracji silnika, które zostały omówione wcześniej. Konstrukcja samolotów będzie wymagać stworzenia silników, które mogą znajdować się nad samolotem lub w bryle samolotu i w skrzydłach. Oznacza to bezpieczną konstrukcję w zakresie ukierunkowania strumienia powietrza zanim trafi on na łopatki wentylatora oraz wyzwania w zakresie certyfikacji, np. w odniesieniu do badań symulujących destrukcję wirnika, skutkującą oderwaniem jednej lub kilku łopatek (FBO). Jednak łatwiejsze będzie

Blade Off"). However, it will lead to an easier task to fulfill noise certification targets, since the noisy components such as the jet can be treated within the aircraft itself or radiate upwards without hurting the neighborhoods of the airport.

\section{Conclusion}

The ACARE VISION 2050 sets extremely challenging targets for an efficient air transport system in the next decades. This leads to the requirement to develop new aircraft and propulsion system concepts. There exist a significant amount of options, targeting at different areas. New thermodynamic cycle considerations compete with new combustion concepts and alternative fuels. Replacing different power systems by just electric power is also an option, which needs significant changes in aircraft architecture, as the integration of the engine into new aircraft types does. The impacts of these various possibilities have been discussed in this paper.

The main conclusion to improve the air transport system can only be, that there needs to be joint efforts taken by engine manufacturers, aircraft designers, airport and air traffic control managers and all disciplines involved in aerospace. So the need for integrated project teams (IPT), as currently established in single entities needs to be extended across companies, countries and organizations. A very good approach to address this is to continue and create joint research programs on a European and international basis.

Prof. Dieter Peitsch, DEng. - Chair for Aero Engines, Institute of Aeronautics and Astronautics Technical University of Berlin, Deutschland.

Prof. dr inż. Dieter Peitsch-profesor w Instytucie Aeronautyki i Astronautyki Politechniki w Berlinie, Niemcy.

e-mail:dieter.peitsch@tu-berlin.de spełnienia wymagań certyfikacyjnych takich jak ograniczenie hałasu, co uwolni od zgiełku okolice lotniska.

\section{Wnioski}

Projekt VISION 2050 wyznacza bardzo ambitne cele stworzenia efektywnego systemu transportu lotniczego na następne dziesięciolecia. Stwarza to potrzebę opracowania nowych konstrukcji samolotów i układów napędowych. Istnieje znaczna liczba rozwiązań do zastosowania w różnych obszarach. Nowy obieg termodynamiczny pod wieloma względami może wspomagać wprowadzanie nowych koncepcji spalania i paliwa alternatywne. Wymiana różnych systemów napędu urządzeń pomocniczych na napęd czysto elektryczny jest także rozwiązaniem, które wymaga znaczących zmian w konstrukcji samolotów, takich jak umiejscowienie silnika w nowym typie statku powietrznego. Skutki tych różnych możliwości zostały omówione w niniejszym artykule.

Główny wniosek odnoszący się do poprawy systemu transportu lotniczego może być tylko taki, że należy podjąć wspólne działania: producentów silników, projektantów samolotów i lotnisk oraz kierowników kontroli ruchu lotniczego i pracowników wszystkich dziedzin związanych z lotnictwem. Tak więc istnieje potrzeba utworzenia zintegrowanych zespołów projektowych (IPT), które z pojedynczych podmiotów muszą być rozszerzone na całe firmy, kraje i organizacje. Bardzo dobrym rozwiązanie jest kontynuowanie oraz tworzenie wspólnych programów badawczych na arenie europejskiej i międzynarodowej. 